\title{
ВПЛИВ КОГНІТИВНИХ ЕВРИСТИК НА ПРОЦЕС ПРИЙНЯТТЯ РІШЕННЯ МАЙБУТНІМИ ОФІЦЕРАМИ НАЦІОНАЛЬНОЇ ГВАРДІЇ УКРАЇНИ В НЕСТАНДАРТНИХ СИТУАЦІЯХ
}

\author{
Конаржевська В. I. \\ кандидат педагогічних наук, доцент, \\ доцент кафедри філологї, перекладу та стратегічних комунікачій \\ Начіональна академія Наџіональної гвардії Украӥни \\ майдан Захисників Вітчизни, 3, Харків, Україна \\ orsid.org/0000-002-9018-5349 \\ viktiv1965-2@ukr.net
}

\author{
Ключові слова: \\ курсанти, евристичне \\ навчання, вміння і навички, \\ розумова діяльність, \\ мислення.
}

Формування вмінь і навичок майбутніх офіцерів Національної гвардії України приймати рішення в нестандартних ситуаціях пов'язане 3 низкою питань, зокрема теоретико-методологічного характеру. Один 3 основних чинників рішення цієї проблеми вбачається в когнітивних евристиках. Визначено, що, незважаючи на велику кількість праць, присвячених дослідженню різних аспектів професійного становлення майбутніх офіцерів Національної гвардії України, поки не створено чіткої концепції, яка б дала змогу приймати рішення в нестандартній ситуації завдяки евристикам.

Мета статті полягає в уточненні показників когнітивних евристик, необхідних дляприйняття рішення майбутніми офіцерами в нестандартних ситуаціях, висвітленні їхніх характеристик для вироблення цілісного уявлення і розуміння цього поняття, а також викладення власного бачення щодо методологічної основи формування необхідних вмінь і навичок майбутніх офіцерів за рахунок евристик.

3'ясовано, що технологія евристичного навчання передбачає використання відповідних методів, які відіграють вирішальну роль у передачі послідовних фаз рішення, і характеризують евристики як інтелектуальні, що залежать від конкретної сфери і спрямовані на прийняття рішення певних проблем. Основна функція евристик -переформулювання проблемної ситуації, виділення значущих умов, акцентування уваги на помилках. Їх використання компенсує брак часу на обмірковування проблемної ситуації з урахуванням перевантаженості інформацією. Встановлено, що евристики можуть призводити також до помилок. Ідеї 3 минулого досвіду можуть стати на заваді альтернативних рішень та генерації нових ідей, чому сприяють когнітивно-емоційні пастки.

Доведено, що оптимальною методологічною основою для формування вмінь i навичок майбутніх офіцерів НГУ приймати рішення в нестандартній ситуації буде така модель, що грунтуватиметься на усвідомленні проблемності поставлених завдань, визначенні значущості рішення проблемних ситуацій та вмінні бачити й аналізувати їх, виділяючи конкретно проблеми і завдання. Зазначене сприяє мисленню за межами звичних суджень. 


\title{
THE INFLUENCE OF COGNITIVE HEURISTICS ON THE DECISION-MAKING PROCESS BY FUTURE OFFICERS OF THE NATIONAL GUARD OF UKRAINE IN NON-STANDARD SITUATIONS
}

\author{
Konarzhevska V. I. \\ Candidate of Pedagogic Sciences, Associate Professor, \\ Senior Lecturer at the Department of Philology, Translation and Strategic Communications \\ National Academy of the National Guard of Ukraine \\ Zakhysnykiv Vitchyzny sq., 3, Kharkiv, Ukraine \\ orsid.org/0000-002-9018-5349 \\ viktiv1965-2@ukr.net
}

Key words:

cadets, heuristic learning, abilities and skills, mental activity.
The formation of skills and abilities of future officers of the National Guard of Ukraine to make decisions in unusual situations is associated with a number of issues, including theoretical and methodological nature. One of the main factors in solving this problem is seen in cognitive heuristics. It is determined that, despite the large number of works devoted to the study of various aspects of the professional development of future officers of the National Guard of Ukraine, a clear concept that would allow decision-making in an unusual situation due to heuristics has not been created yet.

The purpose of this article is to clarify the indicators of cognitive heuristics needed for decision-making by future officers in non-standard situations, highlight their characteristics to develop a holistic view and understanding of this concept, as well as set out their own vision of the methodological basis for forming the necessary skills of future officers.

It has been found that heuristic learning technology involves the use of appropriate methods that play a crucial role in the transmission of successive phases of decision, and characterize heuristics as intelligent, dependent on a specific area and aimed at solving certain problems. The main function of heuristics is to reformulate the problem situation, highlight significant conditions, and focus on errors. Their use compensates for the lack of time to consider the problem situation, taking into account the congestion of information. It has been established that heuristics can also lead to errors. Ideas from past experience can hinder alternative solutions and generate new ideas, which is facilitated by cognitive-emotional traps.

It is proved that the optimal methodological basis for the formation of skills and abilities of future NGU officers to make decisions in a non-standard situation will be a model based on awareness of the problem, determining the importance of solving problem situations and being able to see and analyze them, highlighting problems and tasks. This promotes thinking outside the usual judgments.
Постановка проблеми. Вміння приймати рішення $\epsilon$ важливою складовою частиною професійної діяльності офіцера Національної гвардії України (далі - НГУ). Особливого значення такі навички набувають для вирішення нестандартної ситуації. Як свідчить практика, випускникам, що отримали чудові академічні знання, інколи бракує майстерності знайти правильне рішення, формулювання якого залежить від багатьох чинників. Процес прийняття рішення важко піддається дослідженню, тому що він індивідуальний. Практично неможливо створити дослідницьку ситуацію для аналізу формування нестандартного рішення, бо важливого значення набувають реальні умови, в яких і приймається це рішення [1, с. 27]. Виникає питання, завдяки чому можна сформувати необхідні вміння. Конкретизуюче джерело аналізу проблеми вбачається в дослідженні когнітивних евристик, які можна охарактеризувати як свідомий чи несвідомий процес, пов'язаний з отриманням інформації, iї перетворенням, запам'ятовуванням і використанням задля досягнення мети.

Проблема організації евристичного навчання вивчалася 3 точки зору психології, педагогіки, філософії (П. Гальперін, В. Крутецький, А. Кудряшов, А. Хуторський та інші). Реалізація евристик в 
освітньому процесі як форми мислення викладена у працях Ю. Кулюткіна, В. Соколова. Питання стосовно особливостей прийняття рішень військовими аналізувалися в роботах С. Поздишева, Б. Теплова, А. Шрамченка та інших. Однак окреслена проблематика не $є$ нині вичерпно дослідженою. Аналіз наукової літератури засвідчив, що вона не була предметом спеціального дослідження в царині професійної підготовки майбутніх офіцерів НГУ. Зокрема, не створено чіткої концепції щодо формування вмінь і навичок курсантів приймати рішення в нестандартних професійних ситуаціях за рахунок евристик.

Мета статті полягає в уточненні показників когнітивних евристик, необхідних для прийняття рішення майбутніми офіцерами Національної гвардії України в нестандартних ситуаціях.

Виклад основного матеріалу дослідження. Евристична професійна ситуація виступає засобом засвоєння теоретичних знань, що є підгрунтям професійних компетентностей майбутнього фахівця. Під час формування етапу цих теоретичних знань важливими є такі методи: асоціацій та аналогій; фокальних об'єктів; синектики; емпатії; інверсіі; мозкового штурму. Типовими умовами застосування цих методів є дефіцит часу на обмірковування проблемної ситуації та перевантаженість інформацією, яка ускладнює процес іiі розуміння. Використовуючи зазначене, майбутній спеціаліст адаптується до особливостей його подальшої професіональної діяльності, в нього формуються навички аналізу інформації, діагностики проблемних питань, їх вирішення, внесення до процесу професійного навчання практичного досвіду [2]. Необхідність у нестандартному рішенні виникає тоді, коли створюється проблемна ситуація чи виникають протиріччя щодо іiі вирішення. Нешаблонні або критичні ситуації вимагають як інтелектуального, так й емоційного напруження, навіть стресу внаслідок відсутності в пам'яті (або підсвідомості) варіантів поведінкового рішення.

Інформаційна модель пам'яті складається 3 сенсорної, довгої та короткочасної. Для сенсорної пам'яті важливими є зоровий, слуховий, тактильний та інші органи людини. Довгострокова пам'ять - це сховище інформації, яка може зберігатися необмежено довго. Що стосується короткочасної пам'яті, то безпосередньо в ній здійснюється процес прийняття рішень. Короткочасна пам'ять збирає дані не тільки із зовнішнього світу, а й довготривалої пам'яті. Те, що міститься в короткочасній пам'яті, порівнюється зі змістом свідомості. Саме цей процес дає змогу отримувати інформаційний результат та формувати необхідні дії [3; 4], а отже, відбувається взаємозв'язок новизни 3 отриманими результатами, що є проявом творчості мислення.
Д. Канеман наголошує, що під час прийняття рішення неважливо знати, мислимо ми чи ні. Сутність питання полягає в тому, як ми мислимо, якою мірою вдалі результати від прийнятих рішень грунтуються на вміннях чи просто на везінні. Тому автор виділяє «інтуїтивне (швидке)» та «усвідомлене (повільне)» мислення. Інтуїтивне мислення сприяє знаходженню рішення без первинного логіко-евристичного міркування, використовуючи лише підсвідомість або певну інформацію, яка не включена до активної роботи свідомості. Вона пов' язує власний досвід та вроджені задатки і $є$ неусвідомленою. Усвідомлене мислення - це критичне мислення, де проявляються самостійність, рефлексивність, цілеспрямованість, обгрунтованість. Інтуїтивне та усвідомлене мислення дослідник розмежовує як експліцитну та імпліцитну системи («Система 1» та «Система 2»). Експліцитне мислення характеризується несвідомим прийняттям рішень, відчуттям, інтуїцією, намірами, почуттями, обробкою одного потоку інформації, відсутністю логіки та статистики, схильністю до всіх упереджень відразу. Імпліцитне розкривається через усвідомлене і «повільне» прийняття рішень, перетворення відчуття й інтуїції в переконання, стеження за поведінкою, цілеспрямований вибір та дії [4].

3 точки зору когнітивної психології, у процесі прийняття рішень беруть участь такі мисленнєві операції, як аналітичність, синтетичність, бачення причин і наслідків, схильність до експерименту, формування професійно-теоретичного мислення, а також евристичні методи мислення. Якщо результату не досягнуто і рішення не прийнято, необхідно використовувати кількість стратегій для отримання кінцевого результату. При цьому ускладнюється процедура вибору альтернативних шляхів розв'язання, а задача стає невирішеною, якщо стратегії прийняття рішень не адекватні цільовій програмі [5; 6]. Аналіз ситуації має входити в сутність виникнення рішення, що i $є$ мисленням. Такі порівняно загальні способи прийняття рішення називаються «евристичними методами мислення». У реальному мисленнєвому процесі методи евристики відіграють вирішальну роль для передачі послідовних фаз рішення.

А.В. Хуторський характеризує евристику як спрямованість діяльності людини на створення нею суб'єктивно чи об'єктивно нового і значущого продукту [7, с. 26].

E.I. Скафа [8] вважає, що евристичними прийомами розумової діяльності виступають такі:

- аналіз на основі синтезу - пізнання нових якостей і властивостей об'єктів шляхом включення їх до системи зв'язків і відношень, де вони можуть бути виявлені;

- порівняння дає змогу встановити схожі та відмінні риси предметів і явищ; 
- абстрагування спрямоване на визначення істотних та неістотних властивостей об'єктів;

- узагальнення допомагає виявити об'єднуючі істотні властивості, характерні для множини об'єктів;

- систематизація спрямована на упорядкування об'єктів у систему на основі загального принципу;

- класифікація дає змогу зарахувати одиничне до відповідного роду чи класу;

- аналогія сприяє отриманню нових знань про предмети і явища на підставі часткової схожості 3 іншими;

- формулювання висновків.

Зазначені якості евристик відображуються у функціях евристичних стратегій: виявляти ключові умови задачі, полегшувати іiі переформулювання, відтворювати пошук особистих помилок, керувати своїм креативним мисленням. Як бачимо, евристики інтелектуальні, вони залежать від конкретної сфери і спрямовані на прийняття рішення певних проблем.

Теорії щодо евристики (теорія «мінімізації зусиль», коли людина через власну когнітивну лінь використовує евристики, необхідні для прийняття рішення; теорія «підміна поняття», сутність якої полягає в заміні складних багатозначних питань аналогічними, але більш простими, та теорія «швидко і економно», коли евристики використовуються для швидкого прийняти рішення) - це зазвичай примітивні правила і ментальні стратегії. Використовуючи лише евристичні стратегії, вирішити проблему не вдасться. Основна їх функція - це переформулювання проблемної ситуації, виділення значущих умов, акцентування уваги на зроблених помилках тощо. Це дає змогу полегшити аналіз та розуміння проблеми, генерування нових ідей, що сприятиме формуванню незвичних ідей і рішень, формуючи креативність мислення. Навіть якщо оптимальне рішення не приймається, невдачі не буде, бо в процесі використання цих теорій виникають запитання, здатні формувати креативність мислення.

Використання евристик має не тільки позитивні сторони, вони можуть призводити і до помилок. Ідеї з минулого досвіду, які спрацювали, можуть стати на заваді альтернативних рішень та генерації нових ідей. Евристики здатні приводити до неточних міркувань про явища, а також сприяти виникненню стереотипів й упереджень, ігноруючи релевантну інформацію i створюючи стереотипні категоризації, що не відповідають дійсності. Цьому сприяють когнітивно-емоційні пастки: нездатність побачити явне протиріччя; надмірна впевненість; мислення на користь бажаного або інтерпретація фактів, повідомлень, подій із бажаними очікуваннями, а не згідно 3 реальними доказами або свідченнями; пастка раціоналізації; пристрасть; ефект суб'єктивного підтвердження; залежність від емоційного стану [9; 10].

Згідно $з$ дослідженнями, більш вигідне рішення та його низькі ризики приймаються у стані спокою. 3 іншої сторони, негативні емоції змушують зосередитися не на можливих перевагах, а на недоліках рішення. При цьому обирається певна лінія поведінки, яку потім буває важко змінити. Це ситуації - так звані поведінкові пастки, які поділяються на власне пастки (вибір потенційно небезпечного шляху) та контрпастки (уникнення потенційно вигідної поведінки):

- пастки-відстрочки, сутність яких полягає в миттєвому потаканні своїм слабкостям із довгостроковими наслідками;

- пастки-наведення, коли відсутні знання або інформація про наслідки свого рішення; нерозуміння та непередбачуваність небезпеки;

- інвестиційні пастки - вкладення ресурсів, які в інших умовах не мали б місця;

- пастки ситуації, що погіршується. Початковий образ дій поступово стає менш обгрунтованим i/або більш шкідливим;

- колективні пастки, коли прагнення однієї людини ведуть до несприятливих наслідків усього колективу.

Якщо не фіксувати поведінкові пастки, можуть виникнути серйозні наслідки, тому глибоке розуміння процесів оцінювання покращить якість прийняття рішення [10;11].

Висновки. За допомогою евристик майбутній офіцер НГУ буде здатним створювати та підтримувати відповідні умови, які сприятимуть прийняттю необхідного рішення, підвищувати ефективність мислення, добирати інтелектуальні засоби 3 метою віднайти необхідне рішення в нестандартній ситуації. Евристичне навчання сприяє усвідомленню проблемності поставлених завдань, визначенню значущості рішення проблемних ситуацій та вмінню бачити й аналізувати ix, виділяючи конкретно проблеми i завдання. Беручи до уваги викладене, майбутні офіцери рано чи пізно вийдуть за межі звичних суджень.

\section{Література}

1. Надлер Д. Мышления полного спектра / Дж. Надлер, Ш. Хибино, Дж. Фаррелл ; пер. с англ.; худ. оформ. М.В. Драко. Минск : ООО «Попурри», 2001. 464 с.

2. Білоцерковець М.А. Професійні ситуації в евристичному навчанні гуманітарних дисциплін. Педагогічні науки: теорія, історія, інновачійні технології. 2016. № 10 (64). С. 187-196. 
3. Рубанець О. М. Когнітивний креатив у вимірах когнітивних практик / Вісник Національного технічного університету України «Київський політехнічний інститут». Філософія. Психологія. Педагогіка: зб. наук. праць. 2015. 2(44). С. 89-96.

4. Канеман Д. Мислення швидке й повільне. Київ, 2017. 479 с.

5. Когнітивні компоненти в психології прийняття рішень інтелектуальним агентом / Л.С. Сікора, Р.Л. Ткачук, I.P. Манишин, К.M. Березяк. URL: https://nuczu.edu.ua/sciencearchive/ProblemsOfExtre meAndCrisisPsychology/vol2/25.pdf.

6. Воронін А. І. Проблеми когнітивного розвитку студентів у процесі професійного навчання. Кривий Ріг: ДВНЗ «КНУ», 2012. 112 с.

7. Хуторской А.В. Дидактическая эвристика. Теория и технология креативного обучения. Москва : Изд-во МГУ, 2003. 416 с.

8. Скафа Е.И. Методические основы построения компьютерных программ управления эвристической деятельностью школьников. Информатизация образования. Интеграция информационных u педагогических технологий : материалы Международной научной конференции. Минск, 2008. C. $501-505$.

9. Х Халперн Д. Психология критического мышления. Санкт-Петербург : Питер, 2000. 360 c.

10. Плаус С. Психология оценки и принятия решений / Перевод с англ. Москва : Информационно-издательский дом «Филинъ», 1998. 297 с.

11. Поздишев С.О. Значення прийняття управлінського рішення під час проведення антитерористичної операції. Спеціальна спрямованість фізичної підготовки як складова особистої безпеки військовослужбовиів : матеріали науково-методичного семінару, Київ, 17 без. 2015 р. / М-во оборони України, Нац. ун-т оборони України ім. Івана Черняховського. Київ : НУОУ, 2015. С. 14-16.

\section{References}

1. Nadler D. (2001). Myshleniya polnogo spektra [Full spectrum thinking] / [translation from English; design M.V. Drako]. Mn: OOO "Popurri”, 464 p. [in Russian].

2. Bilotserkovets M.A. (2016). Profesiyni sytuatsiyi v evrystychnomu navchanni humanitarnykh dystsyplin [Professional situations in heuristic learning of humanities] / Pedahohichni nauky: teoriya, istoriya, innovatsiyni tekhnolohiyi, № 10 (64), pp. 187-196. [in Ukrainian].

3. Rubanets O.M. (2015). Kohnityvnyy kreatyv u vymirakh kohnityvnykh praktyk [Cognitive creativity in the dimensions of cognitive practices] / Visnyk Natsionalnoho tekhnichnoho universytetu Ukrayiny „Kyyivs'kyy politekhnichnyy instytut". Philosophy. Psychology. Pedagogy: zb. nauk. Prats, 2(44), pp. 89-96 [in Ukrainian].

4. Kaneman D. (2017). Myslennya shvydke i povilne. Kyyiv, 479 p. [in Ukrainian].

5. Sikora L.S., Tkachuk R.L., Manyshyn I.R., Berezyak K.M. Kognityvni komponenty v psychologii pryjnyattya rishen' intelektual 'nym agentom [Cognitive components in the psychology of decision making by an intellectual agent]. URL: https://nuczu.edu.ua/sciencearchive/ProblemsOfExtremeAndCrisisPsychology/vol2/25.pdf [in Ukrainian].

6. Voronin A.I. (2012). Problemy kohnityvnoho rozvytku studentiv u protsesi profesiynoho navchannya [Problems of cognitive development of students in the process of professional training]. Kryvyy Rih: DVNZ "KNU”, 112 p. [in Ukrainian].

7. Khutorskoy A.V. (2003). Didakticheskaya evristika. Teoriya i tehnologiya kreativnogo obucheniya. Moscow: MGU, 416 p. [in Russian].

8. Skafa O.I. (2008). Metodicheskiye osnovy postroyeniya komp'yuternykh programm upravleniya evristicheskoy deyatel'nost'yu shkol'nikov / Informatizatsiya obrazovaniya. Integratsiya informatsionnykh i pedagogicheskikh tekhnologiy: materialy Mezhdunarodnoy nauchnoy konferentsii [Methodological foundations for the construction of computer programs for the management of heuristic activities of schoolchildren / Informatization of education. Integration of information and educational technologies: materials of the International Scientific Conference]. Minsk, pp. 501-505 [in Russian].

9. Khalpern D. (2000). Psikhologiya kriticheskogo myshleniya [Psychology of critical thinking]. SPb.: St. Petersburg, 360 p. [in Russian].

10. Plaus S. (1998). Psikhologiya otsenki i prinyatiya resheniy [Psychology of assessment and decision making] / translation from English. M.: Informatsionno-izdatel'skiy dom "Filin", p. 297 [in Russian].

11. Pozdyshev S.O. (2015). Znachennya pryynyattya upravlinskoho rishennya pid chas provedennya antyterorystychnoyi operatsiyi [The importance of making management decisions during an anti-terrorist operation]. Materialy naukovo-metodychnoho seminaru "Spetsialna spryamovanist fizychnoyi pidhotovky yak skladova osobystoyi bezpeky viyskovosluzhbovtsiv". The Ministry of Defense of Ukraine, the Ivan Chernyakhovsky National University of Defense of Ukraine. Kyiv, NUDU, pp. 14-16 [in Ukrainian]. 